\title{
The Development of Dialogue Competence in Children (Russian Data Corpus)*
}

\section{Abstract}

The debate regarding linguistic or communicative competence has not subsided since the publication of N.Chomsky's keynote works (Chomsky 1965; 1968). The structure of competence, its aspects, levels and components, and their content and correlation (with regard to both native and foreign language acquisition) are actively discussed in many diverse scientific fields and schools (Pinker, Jackendoff, 2005; Lehmann, 2007). The study suggests that conversational competence, as well as the linguistic-system competence, constitutes a relatively independent component of communicative competence. It also plays an important role in the development of communicative competence, as long as participation in a dialogue serves as a trigger for other types of linguistic competence.

This paper explores the following hypothesis. Although the language-system and dialogue components show traces of parallel development, their divergence may be observed at the early stages of speech ontogenesis. At this time the development of dialogue competence outstrips the development of other linguistic skills and is a catalyst for the formation of communicative competence generally. This study has two primary aims: to investigate some of the normal aspects of the acquisition of dialogue competence (based primarily on communicative failures), and to discover the conductive factors and basic prerequisites for the acquisition of dialogue skills.

The observations are based on the Russian language corpora, including longitudinal audio and video recordings and diary notes (Child Language Database of the Chair of Child Language'). The longitudinal method is the principal method employed in this investigation. Dialogue acquisition is analyzed regarding the extent to which the process relates to the functions of dialogue units initiated by questions.

Analysis of the dialogue skills of children at pre-verbal and early-verbal stages has shown that the communicative failures or breakdowns (just like the child's general mistakes) mark the development of communicative competence in a dialogue and the correlation of different components. Simultaneously developing specific strategies (those of partial understanding, participation and "the end of phrase") enable the child to participate or imitate participation in a dialogue whilst lacking cognitive and

* The research is carried out with financial support of the RF President's Foundation (grant 3433.2010.6 "The School of Functional Grammar in Saint-Petersburg").

Herzen State Pedagogical University of Russia (Saint-Petersburg, Russia); Institute of Linguistic Studies (Russian Academy of Sciences, Saint-Petersburg, Russia). 
linguistic-system skills. The language behavior tactics of the mother are the leading factor in the development of the child's dialogue competence and these tactics, in many respects, are characterized by a specific use of questions ${ }^{2}$.

Key words: child languageacquisition, child-directed speech, dialoguecompetence, communicative failures (breakdowns), question-answer units

\section{Introduction}

The debate regarding linguistic or communicative competence has not subsided since the publication of N. Chomsky's keynote works (Chomsky, 1965, 1968). The structure of competence, its aspects, levels and components, and their content and correlation (with regard to both native and foreign language acquisition) are actively discussed in many diverse scientific fields and disciplines (Pinker, Jackendoff, 2005; Lehmann, 2007).

Dialogue competence, being one of the communicative competence components, implies knowledge of various types of participants' interaction in communication, and an ability to use a corresponding linguistic means. In view of possible differing interpretations of the terms "communicative competence" and "dialogue competence", it seems appropriate to give a working definition of these terms and to suggest a general classification of relevant skills.

We define communicative competence as a functional system of skills, providing a subject of speech, with the ability to participate effectively in all types of communication. The structure includes the language-system component and the communicative component proper; the scope of the language system competence is determined by the realities of language itself. Language-system skills diversify in accordance with language levels, and skills of this kind enable identification of phonological, lexical and grammatical units of the language. Communicative competence proper implies not only the ability to participate in a dialogue, but also the ability to produce a monologue. It includes the skill of using the language system in different ways according to the given situation - that is, the skill to use different models of speech activity in both dialogues and monologues, resulting in "speech experience" (according to Рубинштейн, 1989).

Dialogue competence is represented by a combination of skills related to the way linguistic means function in real communication. On the one hand, it comprises general dialogue skills, providing an ability to react appropriately and maintain the cooperation principle (according to H. P. Grice). These are the skills necessary to produce components of all types of dialogue-units. For instance, these are the skills to exchange phrases which are coherent from the point of view of lexis and grammar, [the] skills to consider the addressee factor, and the

The issue was considered in the report "Development of child's dialogue competence (based on Russian data corpus)" being part of the cross-linguistic seminar "Pre- and Protomorphology in the Language Acquisition" (W. Dresser, The Austrian Academy of Sciences) in February 2009. 
topic-comment relations. On the other hand, these are the specific dialogue skills necessary to generate a dialogue unit of a certain type. These skills depend on the structural-semantic and functional characteristics of a certain opening phrase. Firstly, they are the skills needed to initiate interrogative / imperative phrases of various structural-semantic types and, secondly, the skills needed to adequately reply to such phrases. The accepted concept approaches what researchers call "discourse competence" (D. Hymes), "conversational competence" (M. Tomasello, I. Dimitracopoulou), "communicative competence" (J. Flavell, S. Ervin-Tripp, M. Shatz, K. Meng), "pragmatic competence” (A. Ninio, C. Snow, А. М. Шахнарович) or "linguo - pragmatic competence" (С. Н. Цейтлин).

\section{Aim of the study}

The scope of the research is limited by the early stages of language acquisition, and the aim is to show some important regular features of the development of dialogue competence and to reveal the main prerequisites and factors of the acquisition of dialogue skills. These include adult language behavior and the impact of input (mainly questions) on the child's communicative and cognitive development.

\section{Materials and methods}

\section{Data: Russian language corpora}

The research is carried out based on the Russian language corpus, which includes audio- and video recordings, and longitudinal diary notes. The samples reflect natural communicative interaction between an adult (a mother, usually) and a child. The overall corpus is comprised of the results of the observation of over 30 children, mainly infants (during the second and third years of life). In certain cases data of interaction with infants and of dialogues with children under school age was included ${ }^{3}$. The corpus comprises around 250, 000 dialogue units. Over 50, 000 question-answer units were recorded and analyzed.

\section{Methods of analysis}

Dialogue acquisition is analyzed with regard to the extent to which the process relates to the functions of dialogue units initiated by questions. Due to the above, the object (item) of investigation is dialogue units (cf. the definition of "adjacent pairs"' [Sacks et al., 1974; Schegloff, 1990]), initiated by adult questions. This group comprises a variety of phrases, all of which fall under a certain thematic category or which are united by one micro-topic. Examples of dialogue units which vary in length are given below:

Corpora by T. Gavrilova, V. Kazakovskaja (Institute of Linguistic Studies, Russian Academy of Sciences). 


\begin{tabular}{|l|l|}
\hline $\begin{array}{l}\text { В. (Взрослый): Так а кто ж гулять } \\
\text { пойдет? Ляля или ты? }\end{array}$ & $\begin{array}{l}\text { A. (Adult): So who's going out, you, or } \\
\text { Dolly? }\end{array}$ \\
$\begin{array}{l}\text { комббенок): засовывает куклу в } \\
\text { (Юля К., 1;00) }\end{array}$ & $\begin{array}{l}\text { C. (Child): puts her doll into her jumpsuit } \\
\text { (Julja K., 1;00) }\end{array}$ \\
\hline В.: Хочешь кушать? & \\
Р.: Хочется, Варенька хочет. & A.: Are you hungry? \\
(Варя П., 1;08) & C.: Hungry. Varya is hungry. \\
\hline В.: Дима, кто это? & (Varja P., 1;08) \\
Р.: берет игрушечную лошадь в руки. & A.: Dima, who is this? \\
В.: Дима, кто у тебя в руках? & A.: Dima, who is it in your hands? \\
Р.: Го-го. (Так в это время называет & C: Neigh (a common word for “horse" at \\
лошадку. - Примечание матери.) & this age). \\
В.: Молодец! & A.: Good boy! \\
(Дима С., 1;05) & (Dima S.; 1.05) \\
\hline
\end{tabular}

The longitudinal method, which is widely used to study children's speech, remains the principal method in our investigation, providing it has enabled adequate analysis of the dynamics of dialogue units produced by adult and child in the natural communicative environment. We also found it essential to view the material in terms of semantics and functions $\mathrm{s}^{4}$. As dialogue units are a combination of phases with a certain structure, our research has had to involve structural analysis. In certain cases, analysis of component elements and the use of transformation were deemed to be valuable.

\section{Results}

Communication failures as a mirror of communicative competence development. Our research has shown that communication failures (similar to the child's mistakes, generally) mark the development of a child's communicative competence in a dialogue and the correlation of different components. Communication breakdowns are registered according to the absence of an answer, the presence of incorrect answers or an inadequate reaction of the child.

The following early dialogue fragments illustrate different levels of the development of dialogue competence in similar situations. Accordingly, we can take two early dialogue cases, those related to object/activity identification and object location.

\section{- Wrong answer}

\begin{tabular}{|l|l|}
\hline В.: Что мальчик делает? (О мальчике, & A.: What is the boy doing? \\
собирающем ягоды.) & Sit: about a boy picking berries. \\
Р.: Дядя. & C.: Tata. \\
(Юля К., 1;00) & (Julja K., 1;00) \\
\hline
\end{tabular}

With a view to the functional-semantic approach elaborated by A. В. Бондарко (Bondarko, 1991). 
The child's mother points out that "tata" is a word commonly used by boys at this age.

\section{- Child's inadequate reaction}

В.: Где комбинезон?

Р.: пытается надеть шапку.

(Юля К., 1;00)
A.: Where is your jumpsuit?

C.: is trying to put on her cap.

(Julja K., 1;00)

Communication breakdowns are provoked by a lexical, syntagmatics or paradigmatics deficiency and also by a lack of dialogic technique or cognitive skills.

\section{- Lexical deficiency as a cause of communication breakdown}

В.: A это кто? (указывает на олененка картинку, заинтересовавшую ребенка)

P.: Ммм.

(Юля К., 1;00)
A.: Who is it? (pointing at a picture of a baby deer which has captured the child's attention)

C.: Mmm.

(Julja K., 1;00)

The girl cannot reply due to the lack of correct vocabulary, therefore the reply is merely vocalization. Cf.:

\begin{tabular}{l|l} 
В.: А это что? (о цветке) & A.: And what is this? (of a flower) \\
Р.: делает такое движение, как будто & C.: makes a gesture as if she were sniffing \\
нюхает цветок. & a flower. \\
(Юля К., 1;00) & (Julja K., 1;00)
\end{tabular}

The correct vocabulary is lacking, but the girl overcomes the lexical deficiency by using an iconic or simulation gesture, conveying the "idea of a flower".

In the next example the child uses the pointing gesture in its answer and alerts participants to the situation, using a holophrase from "baby talk", which resembles childish babble:

В.: Юля, кто это? (О нарисованных на картинке мальчике и девочке)

Р. (показывает): Няня, нянь. (Так в это время называет и девочку, и мальчика.) (Юля К., 1;00)
A.: Joulja, who are they? (of a boy and a girl in the picture)

C. (pointing): Baba. ("Baba" is a common word for both "boy" and "girl" at this age.) (Julja K., 1;00)

\section{- Syntagmatics deficiency as a reason for communication breakdown}




\begin{tabular}{|l|l|}
\hline В.: А что делает волк? & A.: And what is the wolf doing? \\
Р.: Сосиску. & С.: Sausage. \\
В.: Скажи: сосиску ест. & A.: Say: eating a sausage. \\
Р.: Лиза. & С.: Lisa. \\
В.: А что Лиза? & A.: Lisa what? \\
Р.: Сосиску. & C.: Sausage. \\
(Лиза Е., 1;09) & (Lisa E., 1;09) \\
\hline
\end{tabular}

The child gives an answer which is formally inadequate: in this case communicative failure is caused by the lack of skills in handling the dialogue syntagmatics. According to the diary-notes of her mother, who is a linguist, the girl had no difficulty in displaying the syntagmatic chain when commenting on her own actions during games.

\section{- Paradigmatics deficiency as a cause of communication breakdown}

\begin{tabular}{|l|l|}
\hline В.: Muть, что делаешь? & А.: Mitja, what are you doing? \\
Р.: Водичку* ногу мыла*. & C.: I was* washing (instead of am washing) water* with \\
(Дима C., 1;09) & my foot (instead of my foot with water). \\
& (Dima S., $1 ; 09$ )
\end{tabular}

The phrase the child uses to reply is completely adequate from the point of view of the dialogue proper and is syntactically full-scale (subject-predicate-instrument). However, we can see that morphological parameters are not acquired. In Russian the verbal form мыла "was washing" has a feminine inflexion. The child uses the accusative instead of the instrumental case of the noun and the past tense instead of the present tense of the verb.

- Lack of dialogue technique and tactics is very serious and the "earliest" difficulty. It implies simultaneous perception of communicative move, planning and production of a reply that would be adequate in terms of lexis and grammar. According to Luria's observations, unsuccessful dialogues with children at an early age exceed $50 \%$ of the dialogue cases (Лурия, 1992).

\begin{tabular}{|l|l|} 
В.: Где «ррр»? Где левушка? (Об & A.: Where is "grr"? Where is the little lion? \\
игрушечном львенке.) & Sit: about a toy lion. \\
Р.: \#. & C.: \#. \\
В.: Вон там левушка, наверху. & A.: That's where the little lion is, up there. \\
(Дима С., 1;00) & (Dima S., 1;00)
\end{tabular}

The child does not answer. The reply position does not contain any initial 
reaction. Answering instead of her child, the mother offers a model of an adequate response: "Where?" - "There".

In the next example the structure of the child's phrase is typical. It conforms to the end-of-the-phrase principle. In this case alteration of the grammatical category of person, which is required due to replication, does not take place. The adult's meta-reaction (2) 5 improves the dialogue:

\begin{tabular}{|l|l|}
\hline (1) В: Ваня, я уже не могу рисовать, я & (1) A.: Vanja, I'm no good, I really can't draw. \\
не умею. & C.: I can draw* (instead of you can draw), I can. \\
P.: Умею* (вместо умеешь), да. & (2) A.: You ought to say "you can". \\
(2) В.: Надо сказать «умеешь». & C.: You can. \\
Р.: Умеешь. & (Vanja J., 2;02) \\
(Ваня Я., 2;02) & \\
\hline
\end{tabular}

- Lack of cognitive skills (certain semantic relations)

\begin{tabular}{|l|l|} 
В. (о воздушном шаре фиолетового & A.: What color is it, Vanechka? \\
цвета): Какого он цвета, Иванушка? Р.: & Sit: about a purple balloon. \\
Темного. & C.: Dark. \\
В.: Вань, ну какого цвета? Какого? & A.: Come on, Vanja! What color is it? \\
Р.: Понюхай. & C.: Have a sniff. \\
(Ваня П., 2;06) & (Vanja P., 2;06) \\
\hline
\end{tabular}

The mother notes that he sniffs the balloon, and then gives it to her. Vanja changes the subject of the conversation because he has seen the color before, but tended to confuse it with blue. This time, to avoid making the same mistake, he prefers to talk about something else.

Cf. the absence of answer in a similar situation:

В.: Сколько пальчиков? (О кукле.)
Р.: \# (Не хочет отвечать.)
Р.: Она идет домой. Прощается.
(Женя М., 2;06)

В.: Сколько пальчиков? (О кукле.)

Р.. \# (Не хочет отвечать.) (Женя М., 2;06)
A.: What color is it, Vanechka?
C.: Dark.
C.: Have a sniff.
(Vanja P., 2;06) 
competence is insufficient at an early age (sеe (Гвоздев, 1961)). It does not mean, however, that dialogue skills do not exist. Imperfect articulation skills, lexical and morphological deficiency do not hinder the child from realizing itself or another person as subjects of interaction due to an adult's communicative behavior (see below).

The most essential language-system skills for forming a child's dialogue competence are related to personal deixis acquisition (the ability to distinguish between itself and the interlocutor: $\mathrm{ME}$ - YOU) and syntax acquisition.

In addition, the acquisition of the categories of modality and modus are treated as actual linguistic factors that facilitate dialogue development. These linguistic categories seem to be nuclear in the process of initial acquisition of dialogue skills by the child. They are significant in order for the child to realize itself as a subject in a dialogue and to perceive that's its own viewpoint may be communicated to a partner or be opposed to another viewpoint. Acquisition of imperative, statements and interrogative paralanguage is based on objective-modal meanings of reality or unreality. Acquisition of the means necessary to express agreement or disagreement, as well as a primary means to manifest a viewpoint by statement is based on modus-meanings, including subjective-modal meanings (Казаковская, 2006).

However, these skills are not the earliest ones displayed. Difficulties in acquisition of syntax skills are due to the large number of variations of a certain model and the possibility of such variation is dictated by the language system. The choice of model and its representation under a certain communication framework are determined by the language norm. As the usage of syntax units is less rigidly regulated than phoneme or morpheme combinations, they are less predictable and therefore more difficult for a child. The degree of relative freedom of choice does not make things easier: most characteristics of an answer in a dialogue are determined by the initiating phrase (in our case, it is a question).

No less important is the fact that a child acquires not the formal model in its "pure form" (regardless of the specific communicative fragments), but specifically "communicative fragments". The child gradually systematizes communicative fragments, and the process results in the formation of standard frames with standard sets of predicates that are associated with lexical syntax models (Tomasello, 2003).

Precursors of the first language-system skills in syntax are: a) the child's reactions to the intonation and melodic contours of speech, which are closely related to the utterance structure; b) proto-signs phrases / one-word-phrases ("holophrases") that enable the establishing of communication and the gaining of understanding with people nearby.

4.2.1. With regard to general dialogue competence, we will focus on different stages of its formation. The pre-verbal stage is characterized by the following. Communicative intentions have purely pre-linguistic expression. The child 
comprehends basic principles of conducting dialogue; that being the mechanism of turn-taking (Якубинский, 1986) and the cooperation principle (H. P. Grice).

It is exercised in primary forms of interaction. By this, we mean'imitative dialogue' and 'proto-dialogue', such as protoconversation, including protochoral singing, dialogues-games, and action-dialogues ${ }^{6}$ (Stern, 1974, 1977; Raser, Bruner, 1978; Snow et al., 1979; Schatz, 1982), and also three types of monologue: monologue proper, subject-oriented and addressed monologues (according to Н. И. Лепская, 1997).

The important landmark in the formation of dialogue falls at the end of the first and at the beginning of the second year of life. At this time proto-signs acquire proper communicative significance, differentiation of proto-sign functions takes place, language-system skills begin to develop, and turn-taking (replication) is activated. The child can fill the reply-position with an adequate or appropriate nonverbal means such as a pointing gesture:

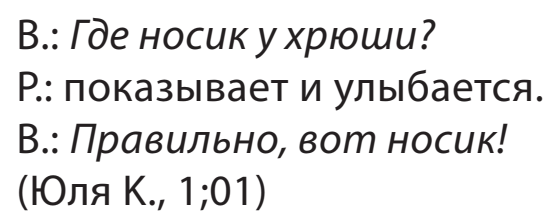

В.: Где носик у хрюши?

Р.: показывает и улыбается.

В.: Правильно, вот носик!

(Юля К., 1;01)

A.: Where is the piglet's nose?

C.: points and smiling.

A.: Right you are, here it is!

(Joulja K., 1;01)

There is no fixed point at which the child starts participating in a dialogue. Transition from pre-verbal to verbal communication, from proto-dialogue to dialogue, is gradual (Казаковская, 2008).

The next important landmark is at the age of two. By the age of two the child initiates a theme and, with the help of conventional verbal means, understands that if the speaker voices something, the answer is "necessitated" and limited by what has been said by the partner. Sometimes the child relies rather more on the form of phrase than on its content. The child tries to eliminate incomplete understanding or misunderstanding in the dialogue: it makes itself "clear" to the partner. Overcoming communication breakdowns is proof of the child's aspiration to succeed in the dialogue.

By the age of three the child is capable of provoking the interlocutor into entering a dialogue, and expressing its viewpoint in the dialogue. It comprehends topic-comment relations and acquires general dialogue competence.

4.2.2. The next issue we are going to discuss is specific dialogue competence or dialogue technique proper. Initially, a child's questions are very infrequent. They reflect "superficial interest" about the location and nomination or identification, although the means of expressing the question semantics can vary. In the middle

Action dialogues belong to routine forms of interaction with a child, and these are initial forms of such interaction (Snow et al., 1982). 
of the third year of life the "question" repertoire expands (Казаковская, 2006).

It coincides with the appearance of practically all types of intonation contour and with the differentiation of locative syncretic one-word-phrases, for instance, "direction" or "location" (Kazakovskaja, 2001). Development of linguistic methods that help express the question semantics, reflects the child's comprehension of the predicate semantics, the valences of the predicate and the functions of interrogative constructions. The child's earliest dictum questions are characterized by the interrogative function proper, while the meta-interrogative function is characteristic of modus questions ${ }^{7}$. The child's replies to an adult's questions are a way of entering into a monologue. Thus, monologue skills develop within dialogue.

Passing on to the evolution of the "adult - child" dialogue, it seems necessary to pay attention to the following aspects that are relevant for the process. We mean reduction of asymmetry in partner interaction, a significant increase in the number of semantically and grammatically coherent phrases in the child's speech, and the development of the child's ability to predict expectations and presuppositions.

As the child grows, conventional usage of phases that correspond to different levels of language-system and cognitive skills development replace the absence of answer and specific "childish" types of answers. The number of successful consecutive dialogue units increases.
(1) В.: Кто это там?
Р.: Таракан.
(1) A.: Who is it over there?
(2) В.: А кто он - таракан?
C.: Cockroach.
P.: Таракан.
(2) A.: And who is he, the cockroach?
C.: Cockroach.
(Дима С., 1;09)
(Dima S., 1;09)

The second question specifies generic subsumption of the relationships between insects. This question is semantically inaccessible for a 19-month-old child. Moreover, the question does not belong to the number of the so-called rehearsed or routine questions. Notwithstanding this, the child responds, directed by the ending of the phrase.

The ability to phrase a question represents the next level of dialogue skill development:

Discussion of the semantic aspect deals with a revealed correlation between dictum and modus questions, on the one hand, and the development of various spheres of the child's verbal intelligence - on the other. Dictum questions are important for linguistic categorization of the surrounding reality, i.e. the objective world, while modus questions are paramount for assimilation of the world of the subjective. Functional type of a phrase is determined by correlation of the functions it performs in the development of dialogue structure and by the purpose of the utterance. The latter is connected with the development of interrogative and meta-interrogative varieties of questions, analyzed in (Kazakovskaja, 2005; Казаковская, 2006). 


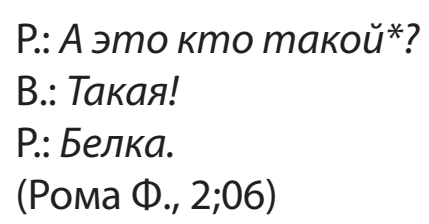

The example shows that the morphological mistake (the masculine gender of the pronoun instead of the feminine: in Russian, белка "squirrel" is a noun of feminine gender) in the child's own question, by no means hinders the dialogue. The answer indicates that the child adequately comprehends the mother's reformulation, which achieves its aim and is thus successful.

In the next case, the interrogative pronoun in the child's question does not conform to the grammatical category of the animate vs. inanimate. The mother gives a conversational reaction:

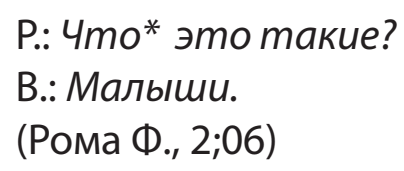

The following situation shows how the child can produce the statement (2), which continues the dialogue. However, grammatical coherence of the statement is marred by the error in the pronoun gender. In the closing phrase the gender error is eliminated, though an element of lexical non-coherence appears. This is due to the choice of a temporal adverb.

\begin{tabular}{|l|l|}
\hline (1) Р.: А где ключик? & (1) C.: And where is the key? \\
В.: Вот он. & A.: Here it is. \\
(2) Р.: А ты мне ё* не отдала. & (2) C.: But you didn't give her (instead of it) to me. \\
В.: Как же не отдала? & A.: Oh, really? Didn't l? \\
$\begin{array}{l}\text { (3) Р.: Нет, ты мне его nотом* не } \\
\text { отдала. }\end{array}$ & (3) C.: No, you didn't give it to me after that* \\
(Варя П., 2;02) & (probably instead of at first/then) \\
\hline
\end{tabular}

Thus the child is quite successful in his interaction technique, yet the development of the lexical-grammatical coherence necessary for genuine (true) replication is still in progress.

Acquiring all the aspects of question-answer typology in each dialogue "role" - those of speaker or listener - makes the child a full partner in the dialogue. Improvement of general dialogue skills and further development of specific dialogue competence is a continuing process that develops throughout childhood. The child's aspiration to communicate helps acquisition of language-system 
skills generally. Dialogue skills acquired by the child appear to be important for development of another dialogue type - that of "child - child". Directing its attention to its partner - initially to an adult and subsequently to a peer, means that the child learns to act as an equal partner in any dialogue.

Conducive factors and basic prerequisites for dialogue competence development. Cognitive conditions and social factors form the basis of dialogue competence development.

1. Cognitive conditions, that help realize the necessity to communicate, are intentionality, intersubjectivity and reciprocity (Trevarthen, 1979; Gopnik, Meltzoff, 1987; Meltzoff, 1995). Research has shown that the initial feeling of intentionality fully matures by the age of 10 months. The existence of a communicative intention is a requirement for entering into communication. The child realizes inter-subjectivity from 12 to 18 months of age. It acquires initial knowledge of the partner's mental states and purposes. Understanding reciprocity (or reciprocal relations) develops rapidly from 12 to 24 months of age.

The starting-point for comprehension of the initial opposition "Me - You" and mastering the semantics of the subjective component of the modus frame are realizing its (the child's) own viewpoint and that of another person, intellectual decentering (according to Piaget), and the ability to differentiate between itself and another person. The dynamics of cognitive development may be presented in the following way: "Me" $\rightarrow$ "another person" $\rightarrow$ and then: "Me and another person". It is comparable with the acquisition of pronominal oppositions: "Me - You" $\rightarrow$ "(MeYou) - (He-She-It)" and the development of modus frames: "Me"-modus frames $\rightarrow$ "You"-modus frames $\rightarrow$ "He"-modus frames.

2. Children learn to speak and "enter" language in different ways, partly by "exotic" cultures (Ochs, Shieffelin, 1984; Lieven, 1994, 1997; Foley, 1997), and partly being guided by adults. In the Russian language culture (and in European culture, speaking generally) the role of the adult in the child's acquisition of basic dialogue mechanisms is vital.

During the first year of life, the mother uses the child's cry to enhance its communicative development. As a result, the child discovers the possibility of entering into communication, and it can observe the effect that its initial, though unintentional, vocalizations produce on the partner. On the whole, the early stages are characterized by the high degree of motherly reaction and the specific mode of her communication with the child which implies that she ascribes certain intentions to the child, models and supports of the dialogue skills that are important in the developing communication. Finally, the mother's speech is characterized by superfluity. This results from violation of the ratio between the principle of economy and aspiration towards reliability (such a ratio is reasonable and necessary in a natural dialogue).

Nevertheless, at the same time there are other factors facilitating dialogue competence development. The following factors pertain to this: a) "communicative 
pressure": opposition "mother - other persons" (father, elder children)" (Tomasello et al., 1984); b) the influence of the functions in which the language is used by an adult, based on the child's idea of the role of language in communication; c) intentional training of the child's communicative skills related to linguistic socialization.

Although the mother's speech-behavior tactics are a crucial factor for dialogue development, it differs considerably even in the latter case. It has been demonstrated by cross-cultural studies of mother-child interactions based on Estonian, Finnish, and Swedish (Tulviste, 2002). Those differences account for the necessity to study the language-specific component of a maternal conversational style. Therefore, we now turn to manifestation of the Russian-language culture.

A Russian mother intuitively observes prototype or canonic dialogue requirements. It means that the mother avoids polysemantic phrases and speech acts. She interprets not only her own speech acts, but also the child's expected response within a certain linguistic and situational context. The mother uses basic structure and types of dialogic units, which enable the logic of communication and the grammar of the dialogue to be revealed.

The specific tactics of a Russian caregiver are largely determined by the use of questions. Meanwhile, the adult's questions are important for the development of both the dialogue and the language-system components of the child's communicative competence. This issue is related to the role of questions in the process of semantic categorization, by means of language, in the acquisition of dialogue technique and tactics and language-system skills, i.e. in acquiring paradigmatics of the principal parts of speech, understanding the essence of topiccomment relations, "defrosting" predicate valences and revealing the syntagmatic chain of the spoken phrase (Казаковская, 2006; Kazakovskaja, 2010, in press).

\section{Conclusions}

The analysis of our data allows us to draw several important conclusions. Participation in dialogue serves as a trigger for other types of linguistic competence. The development of dialogue competence is essentially the acquisition of general and specific dialogue skills. The specific characteristics of communication failures enable us to judge the level of communicative and cognitive development. Communication failures related to the absence of dialogue skills occupy first place in the table of early failures. Second place is occupied by the factor of absence or insufficient development of language-system skills.

The initial stages of development of dialogue grammar may be observed in the second and third years of life. The child's communicative competence is essentially fully-formed by the third year. As the child grows, interaction with it becomes less asymmetrical, and the number of coherent "question-answer" units increases. Initiating the dialogue by putting a question shows a high level of communicative competence and cognitive development. Putting a question is a more complicated 
task than merely replying to one.

The mother's speech-behavior tactics are a crucial factor for dialogue acquisition. An adult's questions are of paramount importance in a child's development of communicative competence. Their communicative and pragmatic diversity makes the initiated "question-answer" units the main means of dialogue formation. The question-answer form of interaction, which is reflected in gradually changing types of speech interaction: "mother-child" - imitative dialogue and various forms of proto-dialogue are the initial methods of creating a dialogue with the child.

\section{References}

1. Balčiūnienè, I. (2009). Analysis of Conversational Structure from the Perspective of Language Acquisition. Summary of the Doctoral Dissertation. Kaunas: Vitautas Magnus University.

2. Bondarko, A. V. (1991). Functional Grammar. A Field Approach. Luelsdorff, F. A. (Ed.). Amsterdam; Philadelphia: J. Benjamins Publishing Company.

3. Chomsky, N. (1965). Aspects of a Theory of Syntax. Cambridge, MA: MIT Press.

4. Chomsky, N. (1968). Language and Mind. New York: Harcourt, Brace \& World.

5. Dressler, W., Kilani-Schoch, M., Balčiūnienè, I., Korecky-Kröll, K., Laaha, S. (2006). The Learnability of Morphology is due to Positive and Negative Evidence. Adult Reactions to Children's Development of French, Lithuanian and German Inflection. In: Paper presented in the $12^{\text {th }}$ International Morphology meeting. Budapest.

6. Foley, W. A. (1997). Anthropological Linguistics. An Introduction. Oxford: Blackwell, p. 474.

7. Gopnik, A., Meltzoff, A. N. (1987). The Development of Categorization in the Second Year and its Relation to the other Cognitive and Linguistic Development. In: Child development, Vol. 58, p. 1523-1531.

8. Kazakovskaja, V.V. (2005). Functions of Questions in "Adult - Child" Dialogues (based on Russian). In: Proceedings of the XInternational congress for the study of child language, Berlin, p. 186.

9. Kazakovskaja, V. V. (2001). Initial Syntax Development: Ontogenesis of Spatial Syntax Structures (based on the language of Russian-speaking children). In: Psychology of language and communication, Vol. 5 (2), p. 51-58.

10. Kazakovskaja, V.V. (2010). Typology of Adult's Questions and Development of Children's Communicative Competence (based on the data of the Russian language corpus). In: Darbai ir dienos, Vol. 53, (in press).

11. Kilani-Schoch, M., Balčiūnienè, I., Korecky-Kröll, K., Laaha, S., Dressler, W. (2008). On the Role of Pragmatics in Child-directed Speech for the Acquisition of Verb Morphology. In: Journal of Pragmatics, Vol. 41 (2), p. 129-159.

12. Lehmann, C. (2007). Linguistic Competence: Theory and Empiry. In: Folia linguistica, Vol. 41 (3/4), p. 223-278.

13. Lieven, E. (1994). Crosslinguistic and Crosscultural Aspects of Language Addressed 
to Children. In: Galloway, C., Richards, B. J. (Eds.). Input and Interaction in Language. Cambridge: Cambridge University Press, p. 56-73.

14. Lieven, E. (1997). Variation in a Crosslinguistic Context. In: Slobin, D. (Ed.) The crosslinguistic study of language acquisition, Vol. 5. Hillsdale, N. J.: Erlbaum, p. 199264.

15. Meltzoff, A. (1995). Understanding the Intentions of others: Re-enactment of Intended Acts by 18-month-old children. In: Developmental psychology, Vol. 54, p. 702-719.

16. Ochs, E., Schieffelin, B. B. (1984). Language Acquisition and Socialization: Three Developmental Stories and their Implicatios. In: Le Vine, R. (Ed.). Culture theory: Essays on mind, self, and emotion. Cambridge: Cambridge University Press, p. 276320.

17. Pinker, S., Jackendoff, R. (2005). The Faculty of Language: What's special about it? In: Cognition, Vol. 95, p. 201-236.

18. Rather, N., Bruner, J.S. (1978). Games, Social Exchange and the Acquisition of Language. In: Journal of child language, Vol. 5, p. 391-401.

19. Sacks, H., Schegloff, E. A. \& Jefferson, G. (1974). A Simplest Systematics for the Organization of Turn-taking in Conversation. In: Language, Vol. 50 (4), p. 696-735.

20. Schegloff, E. A. (1990). On the Organization of Sequences as a Source of "Coherence" in Talk-in-interaction. In: Dorval, B. (Ed.) Conversational organization and its development. XXXVIII: series ADVANCES IN DISCOURSE PROCESSES. Norwood, N. J.: Ablex Publishing Corporation, p. 51-100.

21. Snow, C. E., de Blauw, A., van Roosmalen, G. (1979). Talking and Playing with Babies: The Role of Ideologies of Child Rearing. In: Bullowa, M. (Ed.) Before speech. Cambridge; N.Y:: Cambridge University Press, p. 269-288.

22. Snow, C. E., Dubber, C., de Blauw, A. (1982). Routines in Parent-child Interaction. In: Feagans, L., Farran, D. (Eds.) The language of children reared in poverty: Implications for evaluation and intervention. N.Y.: Academic Press, p. 53-72.

23. Stern, D. (1974). Mother and Infant at Play: The Dyadic Interaction involving Facial, Vocal, and Gaze Behaviors. In: Lewis, M., Rozenblum, L. A. (Eds.) The effect of the infant on its caregiver. N. Y.: John Wiley \& Sons, p. 187-213.

24. Stern, D. (1977). The First Relationship: Mother and Infant. Cambridge: Cambridge University Press, $149 \mathrm{p}$.

25. Tomasello, M., Farrar, J., Dines, J. (1984). Children's Speech Revisions for a Familiar and an Unfamiliar Adult. In: Journal of speech and hearing research, Vol. 27. p. 359363.

26. Tomasello, M. (2003). Constructing a Language: a usage-based Theory of Language Acquisition. Cambridge (Mass.); London: Harvard University Press, 388. p.

27. Trevarthen, C. (1979). Communication and Cooperation in Early Infancy: A Description of Primary Intersubjectivity. In: Bullowa, M. M. (Ed.). Before speech: The beginning of interpersonal communication. N. Y.: Cambridge University Press, p. 321347. 
28. Tulviste, T. (2002). Language Socialization Across Socio-cultural Contexts. Doctoral dissertation, Stockholm: Stockholm University.

29. Гвоздев, А. Н. (2007). Вопросы изучения детской речи [Questions of children's speech study]. Санкт-Петербург: ДЕТСТВО-ПРЕСС, 472 c. (in Russian).

30. Казаковская, В. В. (2006). Вопросо-ответные единства в диалоге «взрослый - ребенок» [Question-answer units in a dialogue "adult - child"]. Бондарко, A. B., Воейкова, М. Д. (Ред.) Санкт-Петербург: Наука, 456 с. (in Russian).

31. Казаковская, В.В. (2008). От протодиалогу к диалогу: коммуникативная компетенция ребенка раннего возраста [From protodialogue to dialogue: child's communicative competence at an early age]. In: Ушакова, Т. Н. (Ред.) Речь ребенка:Проблемы и решения [Speech of child: problems and solutions]. Москва: Издательство Института психологии РАН, c. 169-199. (in Russian).

32. Казаковская, В. В. (2010). Реактивные реплики взрослого и усвоение ребенком грамматики родного языка [Adult's reactions and child's acquisition of grammar]. In: Bonросы языкознания [Issues of Linguistics], Том 3, с. 3-29 (in Russian).

33. Лепская, Н.И. (1997). Язык ребенка (Онтогенез речевой коммуникации) [Language of child (Ontogenesis of communication)]. Москва: Издательство МГУ, 151 c. (in Russian).

34. Лурия, А. Р. (1992). Из дневника за 1938-1941 гг. (Наблюдения за развитием дочери) [From diary of 1939-1941 (Observations of daughter's development)]. In: Вестник МГУ, Сер. 14: Психология, Том 2, с. 12-16. (in Russian).

35. Рубинштейн, С.Л. (1989). Развитие речи у детей [Speech development in children]. In: Рубинштейн, С.Л. Основы общей психологии [Fundamentals of general psychology]., Том I. Москва: Педагогика, c. 460-483. (in Russian).

36. Якубинский, Л.П. (1986). О диалогической речи [About dialogue speech]. In: Якубинский, Л.П. Язык и его функционирование. [Language and its functioning]. Избранные работы. Москва: Наука, с. 17-59. (in Russian).

\section{Senior researcher Dr. philol. Viktorija Kazakovskaja}

Russian Academy of Sciences

Address: Tuchkov per. 9, 199053, St. Petersburg, Russia

Phone: 00-7-812-3284611

E-mail:victory805@mail.ru 